\title{
Türkiye’nin Şehir Sağlığı Politikalarının Sağlık Yönetimi Bakış Açısıyla Değerlendirilmesi
}

\author{
Assessment of Turkey's City Health Policies with Health Management Perspective
}

\author{
Ersin KOCAMAN ${ }^{1}$, Adnan BAÇ², Bahriye TERLEMEZ ${ }^{3}$
}

\begin{abstract}
ÖZ
Bireysel ve toplumsal sağlık değerinin artırılmasında şehir sağlığı politikaları önemli bir role sahiptir. $\mathrm{Bu}$ araştırmada, Türkiye'nin beş yıllık kalkınma planlarında (BYKP) yer alan şehir/kent ile ilgili politikaların tespit edilmesi ve tespit edilen politikaların Dünya Sağlık Örgütü Şehir Sağlık Profilinde yer alan dokuz başlıkta sınıflandırılarak incelenmesi amaçlanmaktadır.

Doküman incelemesi yönteminin kullanıldığı bu araştırmada, 1963- 2023 yıllarını kapsayan on bir tane BYKP incelenmiştir. Veriler, örneklem seçme, kategori geliştirme, analiz birimi saptama ve sayısallaştırma olmak üzere dört aşamada analiz edilmiştir. Verilerin analizinde ve görselleştirilmesinde MAXQDA 2020 ve Microsoft Excel programları kullanılmıştır.

Planlarda, 805 tane şehir sağlığı politikasının var olduğu; politikaların \%51,3'nü (n:413) en son hazırlanan dört BYKP'de, en az politikanın Altınc1 BYKP'de (n:26) ve en fazla politikanın On Birinci BYKP'de (n:142) yer aldığ 1 belirlenmiştir. En az politikanın "Doğal ve Yapay Afetlere Karşı Dayanım" başlığında (n:15), en fazla politikanın ise "Yönetişim ve Katılım" başlı̆̆ında (n:190) olduğu saptanmıştır. Plan başına düşen ortalama şehir sağlığı politika sayısı 73,18 ; , konu başlığı başına düşen ortalama politika sayısı 89,44'tür. Şehir sağlığı politikalarında en sık kullanılan kelimelerin "Sosyal", "Sistem", "Ulaşım", "Su" ve "Koordinasyon" kelimeleri olduğu görülmüştür.
\end{abstract}

Planlarda yer alan şehir sağlığı politikalarının sayısında düzensiz olmakla birlikte ciddi bir artış olmuştur. Sağlı Hizmetleri, Nüfus Yapısı ve Demografik Eğilimler, Doğal ve Yapay Afetlere Karşı Dayanım konularında daha fazla politika üretilmesine ihtiyaç olduğu görülmektedir. Kalkınma planlarında yer alan şehir sağlığı politikalarının sayısının artırılması sağlık değerinin iyileştirilmesine katkı sağlayacaktır.

Anahtar Kelimeler: Politika, Sağlık yönetimi, Şehir, Şehir sağlığ

\begin{abstract}
City health policies have an important role in increasing individual and social health value. In this study, cities located in Turkey's five-year development plan (FYDP) / detection of city related policies and the determined policy of the Profile located in the World Health Organization City Health is aimed classified in nine titles.
\end{abstract}

In this document review method used study, eleven FYDPs covering the years 1963-2023 were examined. Data were analyzed in four stages: sample selection, category development, unit of analysis and digitization. MAXQDA 2020 and Microsoft Excel programs were used in the analysis and visualization of the data.

In the plans, there are 805 city health policies; It has been determined that $51.3 \%$ of the policies (n: 413) are included in the last four FYDPs, the least policy is in the sixth FYDP (n:26) and the most policies are in the eleventh FYDP (n:142). It was determined that the least policy was under the title Resilience to Natural and Man-made Disasters (n:15) and the most under the heading Governance and Participation ( $\mathrm{n}: 190)$ ). The average number of city health policies per plan is 73.18 , and the average number of policies per topic is 89.44. It has been observed that the most frequently used words in city health policies are "Social", "System", "Transportation", "Water" and "Coordination".

There was a serious increase in the number of city health policies included in the plans, albeit irregularly. It seems that there is a need for more policies on Health Services, Population Structure and Demographic Trends, Resilience to Natural and Artificial Disasters. Increasing the number of city health policies included in development plans will contribute to the improvement of health value.

Keywords: Policy, Health management, City, City health

\footnotetext{
${ }^{1}$ Doktora Öğrencisi, Ersin KOCAMAN, Sağlık Yönetimi, İstanbul Medipol Üniversitesi, ekocaman@nku.edu.tr, ORCID: 0000-0002-38251548

${ }^{2}$ Öğr. Gör., Adnan BAÇ, Sağlık Yönetimi, Tekirdağ Namık Kemal Üniversitesi Hemşirelik Bölümü, abac@nku.edu.tr, ORCID: 0000-0002$1452-584 \mathrm{X}$

3 Öğr. Gör., Bahriye TERLEMEZ, Yönetim ve Organizasyon, Tekirdağ Namık Kemal Üniversitesi Tibbi Hizmetler ve Teknikler Bölümü, bterlemez@nku.edu.tr, ORCID:0000-0001-6808-8020

İletişim / Corresponding Author: Ersin KOCAMAN 


\section{GíRiş}

21. yüzyıl "şehirlerin yüzyılı" olarak ifade edilmektedir." Şehirler, ekonomideki değişiklikler, artan yoksulluk, konut kalitesi ve karşılanabilirliği, şiddet ve kirliliğe maruz kalma açısından birçok zorluklarla karşı karşıyadır. ${ }^{2}$ Sağlık sonuçları ise bu zorlukları yakından takip etmektedir. İnsanlar ve yaşadıkları şehirlerarasındaki bağlantıların iyileştirilmesi, sağlık değerinin artırılması için önemlidir. ${ }^{3}$ Sağlıklı insanlar sağlıklı şehirlerde yaşamaktadır. Sağlıklı şehir, sağlık etkisini dikkate alan kamu politikaları ile oluşturulabilir. $^{2}$

$\mathrm{Bu}$ konuda Dünya Sağlık Örgütü'nün (DSÖ) "sağlıklı halk politikası (healthy public policy)" ve "tüm politikalarda sağlık (health in all policies)" olmak üzere iki temel yaklaşımı bulunmaktadır., ${ }^{4,5}$ Sağlıklı halk politikası, kamu politikası oluşturulurken sağlığın dikkate alınmasını sağlamak için sektörler arasında ve tıbbi bakım sisteminin ötesinde çalışmaya odaklanırken, tüm politikalarda sağlı yaklaşımı, kamu politikalarının sağlık belirleyicileri üzerindeki sonuçlarına vurgu yapmaktadır. $\mathrm{Bu}$ yaklaşım, "Toplum sağlığını ve sağlık eşitliğini iyileştirmek için kararların sağlık ve sağlık sistemi etkilerini sistematik olarak hesaba katan, sinerji arayan ve zararlı sağlık etkilerinden kaçınan sektörler arası kamu politikalarına bir yaklaşım" olarak tanımlanırken, politika yapmanın tüm seviyelerinde sağlik etkileri için politika yapıcıların hesap verebilirliğini geliştirmeyi amaçlamaktadır., 5 DSÖ tarafından sağlıklı şehir olma amaciyla stratejiler geliştirebilmesi adına Şehir Sağlık Profili hazırlanmıştır. ${ }^{7}$ Profilde; Sağlık Hizmetleri, Nüfus Yapısı ve Demografik Eğilimler, Konut ve Barınma Koşulları, Kentsel Ekonomi, Sosyal Hizmetler ve Donatılar,
Ulaşım, Çevre ve Ekosistemlerin Sürdürebilirliği, Doğal ve Yapay Afetlere Karşı Dayanım, Yönetişim ve Katılım olmak üzere dokuz başlık yer almaktadır.

Türkiye'de, ekonomik, sosyal ve kültürel alanlarda bütüncül bir yaklaşımla gerçekleştireceği dönüşümleri ortaya koyan temel politika dokümanları olarak kalkınma planları yer almaktadır. Küreselleşme ile birlikte yaşanan ekonomik ve sosyal değişimler kalkınma planlarını önemli bir araç haline getirmiştir. ${ }^{8}$ Türkiye'de on bir tane beş yıllık kalkınma planı (BYKP) hazırlanmıştır. ${ }^{9-19} \mathrm{Bu}$ süreç, 1963 yılında birinci beş yıllık kalkınma planı ile başlamış ve günümüzde 2019-2023 yıllarını kapsayan on birinci beș yıllık kalkınma planı ile devam etmektedir. Kalkınma planlarında ekonomik ve sosyal konulara dair başlıklar arasında şehir/kent ile ilgili birçok politika yer almaktadır. Şehir politikalarında sağlık etkilerinin dikkate alınması, sağlık değerinin artırılmasına katkı sağlamaktadır. Bu araştırmada, birer kamu politikası olan şehir politikalarının sağlık etkileri ile birlikte değerlendirilmesi şehir sağlığı politikaları olarak ifade edilmiştir.

Türkiye'de şehir sağlığı politikalarına ilişkin literatür incelendiğinde herhangi bir araştırmaya rastlanmamıştır. Bu araştırmada, Türkiye'nin beş yıllık kalkınma planlarında yer alan şehir/kent ile ilgili politikaların tespit edilmesi ve tespit edilen politikaların DSÖ Şehir Sağlık Profilinde yer alan dokuz başlıkta sınıflandırılarak incelenmesi amaçlanmaktadır. Araştırma sonuçlarının, ulusal politika yapıcılarına, șehir yönetimlerine ve sağlık yöneticilerine şehir sağlı̆̆ konusunda strateji geliştirebilmeleri adına bir alt yapı oluşturacağı düşünülmektedir.

\section{MATERYAL VE METOT}

\section{Araștırmanın Tipi}

$\mathrm{Bu}$ araștırmada yazılı belgelerin içeriğini analiz etmek için kullanılan, nitel araştırma yöntemlerinden doküman (belge) incelemesi tekniği kullanılmıştır. Doküman inceleme tekniğinde READ yaklaşımı uygulanmıştır. Doküman incelemesi, "bağlam sağlamak, 
sorular oluşturmak, diğer araştırma verileri türlerini desteklemek, zaman içindeki değişimi izlemek ve diğer kaynakları desteklemek için kullanılabilen belgelerin gözden geçirilmesi veya değerlendirilmesi için sistematik bir yöntemdir." ${ }^{20}$ Doküman incelemesi tekniği politika araştırmalarında kullanılan en yaygın yöntemlerden biridir. Doküman incelemesi tekniğinde uygulanan READ yaklaşımı; herhangi bir düzeyde (küresel, ulusal, yerel, vb.) politika çalışmaları bağlamında belge toplamak ve bunlardan bilgi almak için kullanılan sistematik bir prosedürdür. Bu yaklaşım, veri kaynaklarının hazırlanması, verilerin çıkarılması, verileri analiz edilmesi ve bulguların ayrıştırılması olmak üzere dört aşamadan oluşmaktadır. ${ }^{21,22}$

\section{Araştırmanın Evreni ve Örneklemi}

Araştırmada, ilki 1963 yılında hazırlanan ve 2023 y1lına kadar devam eden toplam on bir tane BYKP veri kaynağı olarak kullanılmıştır. Planlara, Türkiye Cumhuriyeti Cumhurbaşkanlığ 1 Strateji ve Bütçe Başkanlı̆̆g'nın internet sitesinden elektronik ortamda erişilmiştir (Tablo 1).

Tablo1. Türkiye'nin Kalkınma Planları (n:11)

\begin{tabular}{ll}
\hline \multicolumn{1}{c}{ Kalkınma Planları } & Dönemi \\
\hline 1. Birinci BYKP & $1963-1967$ \\
2. İkinci BYKP & $1968-1972$ \\
3. Üçüncü BYKP & $1973-1977$ \\
4. Dördüncü BYKP & $1979-1983$ \\
5. Beşinci BYKP & $1985-1989$ \\
6. Altıncı BYKP & $1990-1994$ \\
7. Yedinci BYKP & $1996-2000$ \\
8. Sekizinci BYKP & $2001-2005$ \\
9. Dokuzuncu BYKP & $2007-2013$ \\
10. Onuncu BYKP & $2014-2018$ \\
11. On Birinci BYKP & $2019-2023$ \\
\hline BYKP: Beş Ylllk Kalkınma Planı &
\end{tabular}

\section{Veri Toplama Araci}

Araştırmanın verileri üç aşamada toplanmıştır. Birinci aşamada, araştırmacılar tarafından oluşturulan "Doküman İnceleme Formu" kullanılmıştır. Planlarda yer alan şehir politikalarını tespit edebilmek amacıyla 4656 sayfadan oluşan on bir tane BYKP alanında uzman 3 araştırmacı tarafindan ayrı ayrı incelenmiştir. Planlarda, "şehir" ve "kent" anahtar sözcükleri bilgisayar ortamında taranmış ve bulunan politikalar forma işlenmiştir. İnceleme sonrası araştırmacılar tarafindan elde edilen formlar birbirleri ile karşılaştırılarak benzerlikleri hesaplanmıştır. Güven düzeyi \%96,7 çıkmıştır.

İkinci aşamada, planlardan elde edilen şehir politikaları, oluşturulan "Sınıflandırma Formu" aracılığıyla her bir araştırmacı tarafından sınıflandırılmıştır. Sinıflandırma formunun oluşturulmasında, DSÖ Şehir Sağlık Profilinde yer alan dokuz başlık kullanılmıştır. Sinıflandırma sonrası araştırmacılar tarafindan elde edilen formlar birbirleri ile karşılaştırılarak benzerlikleri hesaplanmıştır. Güven düzeyi \%91,2 çıkmıştır.

Üçüncü aşamada, sınıflandırılan şehir sağlığı politikaları, literatür desteği ile araştırmacılar tarafından kodlanmıştır.

\section{İstatistiksel Değerlendirmesi}

Veriler, analize konu olan veriden örneklem seçme, kategori geliştirme, analiz birimi saptama ve sayısallaştırma olmak üzere dört aşamada analiz edilmiştir. ${ }^{22}$ Verilerin analizinde ve görselleştirilmesinde MAXQDA 2020 ve Microsoft Excel programları kullanılmıştır.

\section{Araştırmanın Etik Yönü}

Araştırmada kullanılan doküman incelemesi tekniğinin direkt insanlar veya hayvanlar üzerinde etkisi söz konusu değildir. $\mathrm{Bu}$ sebeple araştırmada etik kurul iznine gereksinim bulunmamaktadır.

\section{Araştırmanın Sınırlılıkları}

Araştırma; Türkiye Cumhuriyeti Cumhurbaşkanlığ 1 Strateji ve Bütçe Başkanlığı'nın internet sitesinden elektronik ortamda erişilen on bir tane BYKP'de, "şehir" ve "kent" anahtar sözcüklerinin bilgisayar ortamında taranması ve politikaların DSÖ Şehir Sağlık Profilinde yer alan dokuz başlıkta sınıflandırılması ile sinırlidir. 


\section{BULGULAR VE TARTIŞMA}

Araştırma bulguları, Sağlık Hizmetleri, Nüfus Yapıs1 ve Demografik Eğilimler, Konut ve Barınma Koşulları, Kentsel Ekonomi, Sosyal Hizmetler ve Donatılar, Ulaşım, Çevre ve Ekosistemlerin Sürdürebilirliği, Doğal ve Yapay Afetlere
Karşı Dayanım, Yönetişim ve Katılım başlıkları altında verilmiş ve tartışılmıştır.

Planlarda, "şehir" ve "kent" anahtar sözcüklerinin taranması sonucu 805 tane şehir sağlı̆̆ politikası tespit edilmiştir.

Tablo 2. Şehir Sağlı̆̆ı Politikalarının Planlara ve Konu Başlıklarına Göre Dağılımı

\begin{tabular}{|c|c|c|c|c|c|c|c|c|c|c|}
\hline & SH & NYDE & KBK & KE & SHD & $\mathbf{U}$ & ÇES & DYAKD & YK & Toplam \\
\hline Birinci BYKP (1963-1967) & 2 & 0 & 2 & 11 & 0 & 3 & 7 & 0 & 2 & 27 \\
\hline İkinci BYKP (1968-1972) & 2 & 2 & 21 & 17 & 12 & 7 & 5 & 0 & 14 & 80 \\
\hline Üçüncü BYKP (1973-1977) & 4 & 4 & 7 & 5 & 2 & 2 & 3 & 1 & 8 & 36 \\
\hline Dördüncü BYKP (1979-1983) & 3 & 4 & 12 & 23 & 9 & 21 & 17 & 0 & 21 & 110 \\
\hline Beşinci BYKP (1985-1989) & 2 & 4 & 2 & 14 & 7 & 5 & 7 & 0 & 7 & 48 \\
\hline Altıncı BYKP (1990-1994) & 0 & 3 & 2 & 4 & 4 & 2 & 4 & 0 & 7 & 26 \\
\hline Yedinci BYKP (1996-2000) & 2 & 5 & 9 & 9 & 11 & 9 & 7 & 0 & 13 & 65 \\
\hline Sekizinci BYKP (2001-2005) & 1 & 1 & 11 & 25 & 7 & 28 & 8 & 4 & 36 & 121 \\
\hline Dokuzuncu BYKP (2007-2013) & 0 & 2 & 0 & 0 & 1 & 8 & 23 & 0 & 2 & 36 \\
\hline Onuncu BYKP (2014-2018) & 0 & 4 & 19 & 21 & 12 & 11 & 9 & 1 & 37 & 114 \\
\hline On Birinci BYKP (2019-2023) & 0 & 2 & 17 & 14 & 15 & 22 & 20 & 9 & 43 & 142 \\
\hline Toplam & 16 & 31 & 102 & 143 & 80 & 118 & 110 & 15 & 190 & 805 \\
\hline
\end{tabular}

SH: Sağllk Hizmetleri, NYDE: Nüfus Yapısı ve Demografik Eğilimler, KBK: Konut ve Barınma Koşulları, KE: Kentsel Ekonomi, SHD: Sosyal Hizmetler ve Donatılar, U: Ulaşım, ÇES: Çevre ve Ekosistemlerin Sürdürebilirliği, DYAKD: Doğal ve Yapay Afetlere Karşı Dayanım, YK: Yönetişim ve Katılım, BYKP: Beş Ylllık Kalkınma Planı.

Planlara göre şehir sağlı̆̆ı politikaları incelendiğinde (Tablo 2) ilk olarak hazırlanan ve 1963-1967 yıllarını kapsayan Birinci BYKP'de 27 politika yer alırken en son hazırlanan ve 2019- 2023 yıllarını kapsayan On Birinci BYKP'de 142 politika yer almaktadır. Politikaların \%51,3'nü (n:413) en son hazırlanan dört BYKP'de yer aldığ 1 , en az politikanın Altıncı BYKP'de (n:26) ve en fazla politikanın On Birinci BYKP'de (n:142) yer aldığı görülmektedir. Politika sayılarında en fazla artışın (n:78) Dokuzuncu BYKP ve Onuncu BYKP arasında olduğu ve en fazla azalışın (n:85) Sekizinci BYKP ve Dokuzuncu BYKP arasında olduğu tespit edilmiştir.

Şehir sağlı̆̆ı politikalarının DSÖ Şehir Sağlık Profiline göre sınıflandırılması Tablo 2 'de verilmiştir. Buna göre en az politikanın "Doğal ve Yapay Afetlere Karşı Dayanım" başlığında (n:15) olduğu en fazla politikanın ise "Yönetişim ve Katılım" başlığında (n:190) olduğu görülmektedir. Sekizinci BYKP ve Dokuzuncu BYKP arasinda sadece "Nüfus Yap1s1 ve Demografik Eğilimler" başlığındaki politika sayısı 1, "Çevre ve Ekosistemlerin Sürdürebilirliği" başlığındaki politika sayısı 15 artmış diğer tüm başlıkların politika sayılarında azalma olmuştur. Plan başına düşen ortalama politika sayısı 73,18 'dir. Birinci, Üçüncü, Beşinci, Altınc1, Yedinci ve Dokuzuncu BYKP'ler ortalamanın altında kaldığ 1 görülmektedir. Konu başlığı başına düșen ortalama politika sayısı 89,44'dür. Sağlık Hizmetleri, Nüfus Yapısı ve Demografik Eğilimler, Sosyal Hizmetler ve Donatılar, Doğal ve Yapay Afetlere Karşı Dayanım konularının ortalamanın altında kaldığ 1 görülmektedir.

Planlarda tespit edilen 805 şehir sağlığ politikalarının kelime analizinde 811 kelime bulunmuştur. 
Tablo 3. Şehir Sağlığı Politika Kodlarının Planlara ve Konu Başlıklarına Göre Dağılımı

\begin{tabular}{|c|c|c|c|c|c|c|c|c|c|c|}
\hline & SH & NYDE & KBK & $\mathbf{K E}$ & SHD & $\mathbf{U}$ & ÇES & DYAKD & YK & Toplam \\
\hline Birinci BYKP (1963-1967) & 2 & 0 & 3 & 5 & 0 & 1 & 7 & 0 & 4 & 22 \\
\hline İkinci BYKP (1968-1972) & 3 & 5 & 5 & 5 & 11 & 5 & 6 & 0 & 9 & 49 \\
\hline Üçüncü BYKP (1973-1977) & 3 & 11 & 2 & 1 & 1 & 3 & 4 & 1 & 18 & 44 \\
\hline Dördüncü BYKP (1979-1983) & 2 & 2 & 3 & 9 & 5 & 12 & 26 & 0 & 34 & 93 \\
\hline Beşinci BYKP (1985-1989) & 2 & 4 & 1 & 8 & 6 & 6 & 6 & 0 & 4 & 37 \\
\hline Altıncı BYKP (1990-1994) & 0 & 3 & 1 & 0 & 17 & 2 & 6 & 0 & 7 & 36 \\
\hline Yedinci BYKP (1996-2000) & 12 & 8 & 3 & 4 & 7 & 11 & 18 & 0 & 13 & 76 \\
\hline Sekizinci BYKP (2001-2005) & 9 & 8 & 4 & 6 & 8 & 21 & 10 & 9 & 36 & 111 \\
\hline Dokuzuncu BYKP (2007-2013) & 0 & 9 & 0 & 0 & 1 & 9 & 32 & 0 & 2 & 53 \\
\hline Onuncu BYKP (2014-2018) & 0 & 23 & 8 & 15 & 7 & 13 & 27 & 1 & 38 & 132 \\
\hline On Birinci BYKP (2019-2023) & 0 & 4 & 18 & 10 & 21 & 20 & 17 & 15 & 53 & 158 \\
\hline Toplam & 33 & 77 & 48 & 63 & 84 & 103 & 159 & 26 & 218 & 811 \\
\hline
\end{tabular}

Tablo 3 incelendiğinde, planlara göre kodlar açısından en az kod (n:22) Birinci BYKP'de, en fazla kod (n:158) On Birinci BYKP'de yer almaktadır. Konu başlıklarına göre kodlar açısından da en az kodun (n:26) "Doğal ve Yapay Afetlere Karşı Dayanım" başlığında, en fazla kodun (n:218)
"Yönetişim ve Katılım” başlığında yer aldı̆̆ görülmektedir. Kodların genel değerlendirilmesinde politika sayısında da olduğu gibi en fazla kodun (n:53) On Birinci BYKP'de Yönetişim ve Katılım başlığında olduğu belirlenmiştir.

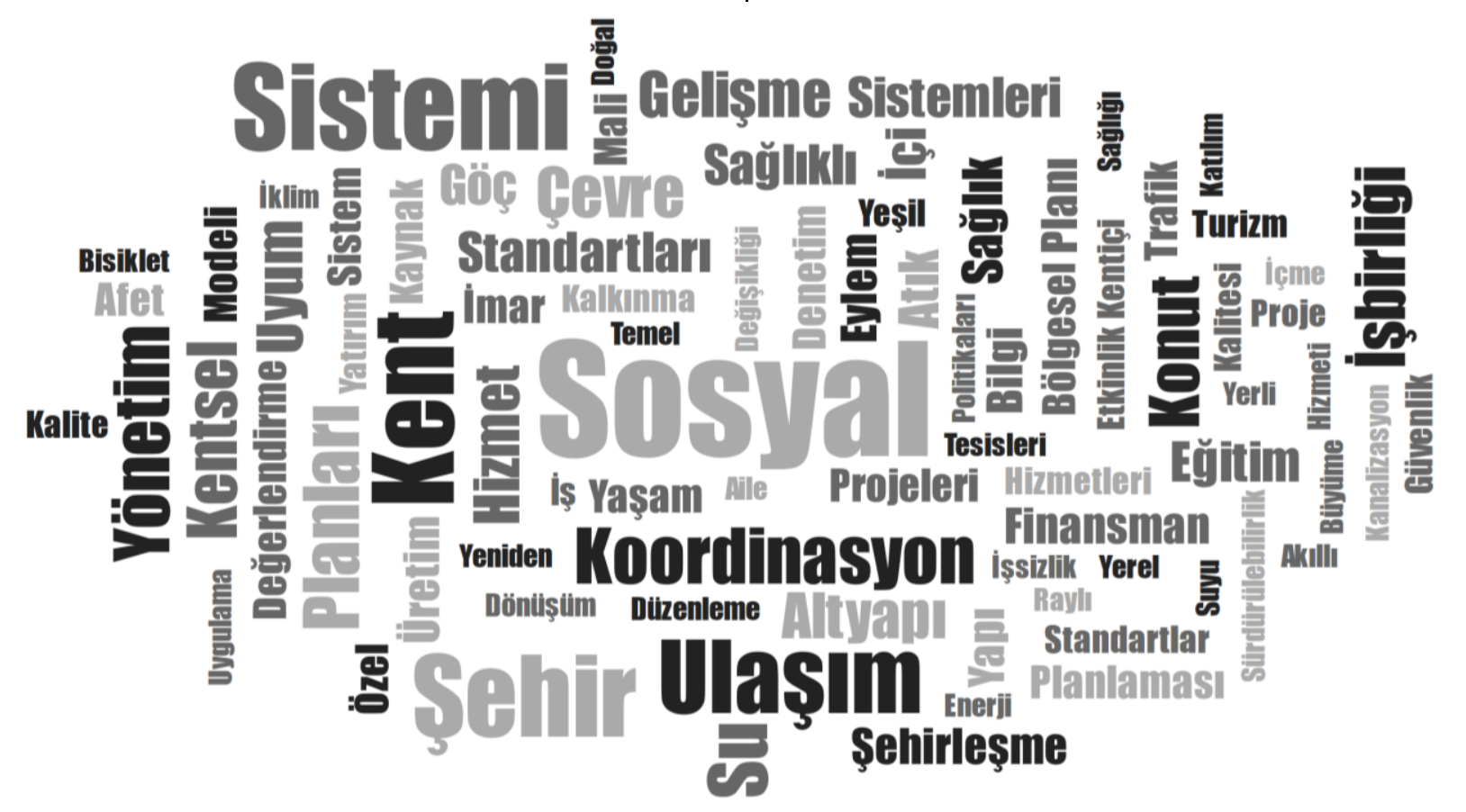

Şekil 1. Şehir Sağlı̆̆ı Politika Kodlarına Ait Kelime Bulutu

Şekil 1'de kelimelerin kodlarda geçme sıklıklarına bağlı olarak şekillenen kelime bulutu yer almaktadir. En s1k tekrarlanan kelime "Sosyal" kelimesidir (n:25). Sosyal dışında "Sistemi" (n:18), "Ulaşım" (n:16), "Su" (n:13), "Koordinasyon" (12) kelimeleri en sık geçen kelimeler olarak öne çıkmaktadır.

\section{Sağlık Hizmetleri}

Tablo 2'de Sağlık Hizmetleri başlı̆̆ altında yer alan politikaların planlara göre dağılımları gösterilmiştir. Sağlık Hizmetleri 
konusunda Altınc1, Dokuzuncu, Onuncu ve On Birinci BYKP'lerde politika yer almazken (n:0) en fazla politika (n:4) Üçüncü BYKP'de yer almaktadır. Sağlık hizmetleri konusunda son 3 planda politika yer almazken son 6 planda sadece 3 politikanın olduğu tespit edilmiştir. Planlarda, Sağlık Hizmetleri başlığı altında yer alan toplam politika sayısı 16'dır. Tablo 3'de planlarda, Sağlık Hizmetleri başlığ altında yer alan toplam kod sayısı 33'dür.

Sağlık hizmetleri başlığında yer alan politikalar incelendiğinde; sağlık hizmetlerinin sosyalleştirilmesi, iş ve işçi sağlı̆̆ı, sosyal güvenlik, dengeli dağılım, koruyucu sağlık hizmetleri, sağlık insan gücü ve sevk zinciri kavramları öne çıkmaktadır. Birinci, İkinci ve Üçüncü BYKP'lerde yer alan kavramlar, bu dönemde halk sağlığı hizmetlerine öncelik verilmesi ile ilişkilendirilebilir. Nitekim 5 Ocak 1961'de kabul edilen "Sağlık Hizmetlerinin Sosyalleştirilmesi Hakkında Kanun" bulgumuzu desteklemektedir. ${ }^{23}$ Sağlıklı kent/şehir ve sağlıklı kentleşme kavramları planlar içerisinde sadece Dördüncü BYKP'de tespit edilmiştir. Bu durum, yeni bir şehirleşme girişimi olarak değerlendirilebilir. Yedinci BYKP ve sonrasinda yer alan kavramların uygulamadaki yansımalarını sağlıkta dönüşüm programı içerisinde görmek mümkündür. ${ }^{24}$ Şehirde yaşayan insanların ihtiyaç duyduklarında sağlık hizmetlerine yerinde ve zamanında hakkaniyetli bir şekilde erişebilmelerinin sağlanması, şehirlerin sağlık hizmeti sunum kapasitelerinin etkililiğini ve etkinliğini artıracak politikalar ile mümkündür. ${ }^{25}$ Sağlık hizmetlerini içeren politikaları şu şekilde örneklendirmek mümkündür:

\section{"Sağllkl beslenme - sağllkl tüketim - sağllklı kentleşmenin birlikte gerçekleştirilmesi, amaçlanmaktadır."12}

"Tarımsal gelişmeyle, hızlı sinaileşmeyi ve sağlıklı bir kentleşmeyi tüm yurda yaygın olarak uyumlulaştırmak."12

\section{Nüfus Yapısı ve Demografik Eğilimler}

Tablo 2'de Nüfus Yapısı ve Demografik Eğilimler başlığı altında yer alan politikaların planlara göre dağılımları gösterilmiştir. Nüfus Yapısı ve Demografik Eğilimler konusunda Birinci BYKP'de politika yer almazken (n:0) en fazla politika (n:5) Yedinci BYKP'de yer almaktadir. Planlarda Nüfus Yapısı ve Demografik Eğilimler başlı̆̆ 1 altında yer alan toplam politika sayıs1 31'dır. Tablo 3'de planlarda, Nüfus Yapısı ve Demografik Eğilimler başlığı altında yer alan toplam kod sayısı 77'dir.

Nüfus Yapısı ve Demografik Eğilimler başlığında yer alan politikalar incelendiğinde; şehirleşme, göç ve sosyal uyum kavramları öne çıkmaktadır. İkinci BYKP'de "şehirleşme" iktisadi ve sosyal gelişmeyi hızlandıran bir nitelik olarak ifade edilirken Üçüncü BYKP'de sanayileşmeyi düzenleyici bir araç olarak ifade edilmektedir. $\mathrm{Bu}$ konuda yer alan tüm kavramlar şehirleşme sonucunda ortaya çıkan gereklilikler, avantajlar ve dezavantajlarla ilişkilendirilebilir. ${ }^{26}$ Şehirleşme politikaları, kişilerin demografik özellikleri, kişisel alışkanlıkları, eğitim, sosyal uyum ve sosyal bağlantı gibi bireysel sağlığın önemli belirleyicilerini doğrudan etkilemektedir. ${ }^{27}$ Nüfus yapısı ve demografik eğilimleri içeren politikaları şu şekilde örneklendirmek mümkündür;

“Köykentler yoluyla, köylünün yerinde kalkınması ve kentlileşmesi sağlanmaya başlayacaktır."12

"Göçle şehre gelen ailelerin şehir yaşamına uyumlarının hızlandırılması."18

\section{Konut ve Barınma Koșulları}

Tablo 2'de Konut ve Barınma Koşulları başlığı altında yer alan politikaların planlara göre dağılımları gösterilmiştir. Konut ve Barınma Koşulları konusunda Dokuzuncu BYKP'de politika yer almazken (n:0) en fazla politika (n:21) İkinci BYKP'de yer almaktadır. Planlarda, Konut ve Barınma Koşulları başlığı altında yer alan toplam politika sayıs1 102'dir. Tablo 3'de planlarda, 
Konut ve Barınma Koşulları başlığı altında yer alan toplam kod say1s1 48'dir.

Konut ve Barınma Koşulları başlığında yer alan politikalar incelendiğinde; imar planı, sosyal konut, kadastro/harita, konut arz ve talep dengesi kavramları öne çıkmaktadır. Tüm planlarda yer alan konut problemi hılı bir şehirleşmenin sonuçları ile ilişkilendirilebilir. Konut ihtiyacının karşılanmasına yönelik planlardaki sosyal konut kavramı bunu desteklemektedir. Onuncu BYKP'de yer alan kavramlar bu dönemde gerçekleşen finansal gelişmelerin bir yansıması olarak okunabilir. ${ }^{28}$ On Birinci BYKP'de yer alan kavramlar ise 21. yy.da yaşanan bilim ve teknolojideki gelişmeler ile sosyal yaklaşımın yansımalarını içermektedir. ${ }^{29}$ Barınma, barınağın ötesinde, konfor, mahremiyet ve güvenlik hissi sağlamaktadır. Araştırmalar, barınma koşulları ile sağlık etkileri arasında güçlü ilişkiler olduğunu göstermektedir. Hem yapısal hem de sosyal ortamı tanımlayan barınma konusundaki politikalar şehir sağlığının en önemli unsurlarından biridir. ${ }^{30}$ Konut ve barınma koşulları içeren politikaları şu şekilde örneklendirmek mümkündür;

"Konut alanında, Türk toplumunun gelecekte ulaşması istenen yaşama şartları göz önünde tutularak, bu şartların gereği olan nicelik ve nitelikte konut yapma faaliyetleri uzun süreli programlarla düzenlenecektir."10

"Gecekondu bölgelerinde yol, su, elektrik ve kanalizasyon gibi altyapılar ve hizmetler hızlandırılacak, gecekondu iyileştirme bölgelerin 'deki kamu arsalarında barınan yurttaşlara uzun süreli kullanma hakk1 tanınacaktır."12

“Kentsel dönüşüm projeleri, farklı gelir gruplarının yaşam alanlarını kaynaştıran, işyeri-konut mesafelerini azaltan, şehrin tarihi ve kültürel birikimiyle uyumlu, sosyal bütünleşmeyi destekleyen bir yaklaşımla gerçekleştirilecektir."18

\section{Kentsel Ekonomi}

Tablo 2'de Kentsel Ekonomi başlığ altında yer alan politikaların planlara göre dağılımları gösterilmiştir. Kentsel Ekonomi konusunda Dokuzuncu BYKP'de politika yer almazken (n:0) en fazla politika (n:25) Sekizinci BYKP'de yer almaktadır. Planlarda, Kentsel Ekonomi başlığı altında yer alan toplam politika sayısı 143'dür. Tablo 3'de planlarda, Kentsel Ekonomi başlığı altında yer alan toplam kod sayısı 63 'dür.

Kentsel ekonomi başlığında yer alan politikalar incelendiğinde, gida ve tarım, istihdam, enerji, işsizlik, turizm, sanayileşme, üretim ve rekabet kavramları öne çıkmaktadır. Kentsel ekonomi açısından tüm planlarda sanayileşmenin önemli bir araç olarak kullanılması söz konusudur. Yedinci BYKP ve sonrasinda yer alan kavramlar küreselleşmenin etkilerinin bu alandaki politikaların oluşumundaki rollerini ifade edebilir. Onuncu ve On Birinci BYKP'de yer alan "yerli üretim" kavramı üretime dayal1 bir kentsel ekonominin benimsendiğinin göstergesidir. ${ }^{31}$ Şehir sağlığı ve kent ekonomi arasında iki yönlü bir ilişki bulunmaktadır. Sağlıklı bir şehir; üretkenliği ve ekonomik çıktıyı artırır, kişisel ve kent gelirini artırır, yatırımı teşvik eder, tasarrufları artırır ve beşeri sermayeyi geliştirir. Bunun yanında ekonominin sağlık sonuçları olarak; ekonomik performansı yüksek olan şehirlerde kişilerin gelirleri de yüksek olur. Bu da kişilerin sağlik hizmet ve ürünlerinden daha çok yararlanarak sağlık değerini artırmalarını sağlamaktadır. ${ }^{32}$ Kentsel ekonomiyi içeren politikaları şu şekilde örneklendirmek mümkündür;

"Şehirleşme desteklenecek ve şehirleşmeden ekonomiyi itici bir güç ve bir gelişme aracı olarak yararlanılacaktır." 10

"Nüfus artışı, kentleşme, sanayileşme ve gelir artışına bağlı olarak kapalı aile ekonomisi içinde ve ev üretimi ile karşılanan talebin pazara yönelmesi sonucunda artmakta olan gıda sanayii ürünleri talebinin, standart ve dış pazarda rekabet edebilecek kalitede, sağlığa uygun, yeterli ve dengeli beslenmeye imkân veren bir üretimle sağlanması ana politika olacaktır."13 
"Görece geri kalmış bölgelerde çevresine hizmet verme bakımından merkez olma işlevi taşıyan illerde Cazibe Merkezlerini Destekleme Programı uygulanmasına devam edilecektir."19

\section{Sosyal Hizmetler ve Donatılar}

Tablo 2'de Sosyal Hizmetler ve Donatılar başlığı altında yer alan politikaların planlara göre dağılımları gösterilmiştir. Sosyal Hizmetler ve Donatılar konusunda Birinci BYKP'de politika yer almazken (n:0) en fazla politika (n:15) On Birinci BYKP'de yer almaktadır. Planlarda, Sosyal Hizmetler ve Donatılar başlığı altında yer alan toplam politika sayıs 80 'dir. Tablo 3'de planlarda, Sosyal Hizmetler ve Donatılar başlığı altında yer alan toplam kod sayısı 84'dür.

Sosyal hizmetler ve donatılar başlığında yer alan politikalar incelendiğinde, eğitim, kültür, sanat, spor ve güvenlik kavramları öne çıkmaktadır. Eğitime yönelik politikalara tüm planlarda yer verildiği görülmektedir. Özellikle şehirleşme ile birlikte eğitim faaliyetlerinin nitel ve nicel olarak arttığı ancak şehirleşmenin beraberinde oluşan dezavantajlı durumların eğitimi de etkilediği düşünülmektedir. ${ }^{33} \mathrm{Bu}$ görüşü, ilgili danışma ve sosyal yardım hizmetleri kavramları desteklemektedir. Sanatsal faaliyetlerle ilgili kavramların İkinci ve Üçüncü BYKP'lerde yer alırken diğer planlarda yer almaması dikkat çekmektedir. Beşinci BYKP'de yer alan kavramlarla kadınların sosyal hayata katılması ile birlikte meydana gelen ihtiyaçların karşılanmasına yönelik politikaların oluşturulduğu anlaşılmaktadır. Tüm planlarda sosyal donatılara yönelik kavramların yer alması şehir sağlığının sosyal yönü açısından önem taşımaktadır. ${ }^{34}$ Teknoloji alanındaki gelişmelerin eğitime ve güvenlik alanlarına yansıması Onuncu ve On birinci BYKP'lerde yer alan kavramlarla anlaşılmaktadır. On Birinci BYKP'de yer alan kavramlarla kalite biliminin oluşturulan politikalardaki etkisi görülmektedir. Bireysel düzeyde sosyal yoksunluk ile kötü sağlık sonuçları arasında kanıtlanmış bir ilişki vardır. Eğitim, kültür, sanat, spor ve güvenlik gibi karşılanmamış sosyal ihtiyaçlar, bireylerin genel sağlık durumunu etkilemektedir. Şehir düzeyinde yoksunluk, şehirde yaşayan insanların bireysel sosyoekonomik durumundan bağımsız olarak fiziksel ve duygusal refahlarını etkilemektedir. $\mathrm{Bu}$ durum şehirde sağlık eşitsizliklerini artmasına neden olmaktadır. Karşılanmamış sosyal ihtiyaçlar ile kötü sağlık sonuçları arasındaki ilişki göz önüne alındığında, bu ihtiyaçların ele alınmasına yönelik politikaların yapılması şehir sağlığı açısından büyük önem taşımaktadır. ${ }^{35}$ Sosyal Hizmetler ve Donatılar içeren politikaları şu şekilde örneklendirmek mümkündür;

"Kentleşme ve gelişme sürecinde insan ve çevre ilişkilerini ve să̆liğıını, ülkenin tarihsel ve doğal zenginliklerini ekonomik bütünlük içinde korumak." 12

"Kentleşme sürecinde tarihi, doğal, sosyal ve kültürel değerlerin korunması ve sağllkll, güvenli, kaliteli, ekonomik konut ve çevrelerin oluşturulması amaciyla yapı ve çevre standartları geliştirilecektir." 16

"Başta açık ve yeşil alanlar olmak üzere şehirlerdeki kamusal alanların korunmas1; erişim ve güvenliğinin artırılması; kadınlara, çocuklara, yaşlılara, engellilere duyarlı olarak insan-tabiat ilişkisi çerçevesinde yeniden kurgulanması sağlanacaktır."19

"Sosyal Destek Programı yeniden yapilandırlacak ve uygulaması yaygınlaştırılacaktır."19

\section{Ulaşım}

Tablo 2'de Ulaşım başlığı altında yer alan politikaların planlara göre dağılımları gösterilmiştir. Ulaşım konusunda Üçüncü ve Altıncı BYKP'lerde en az politika (n:2) yer alırken en fazla politika (n:28) Sekizinci BYKP'de yer almaktadır. Planlarda, Ulaşım başlığı altında yer alan toplam politika sayısı 118'dir. Tablo 3'de planlarda, Ulaşım başlığı altında yer alan toplam kod sayısı 103'dür.

Ulaşım başlığında yer alan politikalar incelendiğinde, alt yapı, şehir içi trafik, otopark, taşıtlar, toplu taşıma, bisiklet ve yaya ulaşımı öne çıkan kavramlardır. İlk üç 
fazla politika (n:23) Dokuzuncu BYKP'de

planda ulaşım alt yapısının iyileştirilmesine yönelik kavramların ağırlıklı olarak yer almaktadır. Yedinci BYKP ve sonrasinda yer alan kavramlarda kalite, planlama, koordinasyon, denetim ve teknoloji vurguları dikkat çekmektedir. Ulaşım, şehir yaşamının kilit unsurlarından biridir. Ulaşımla ilgili politikaların ve projelerin, bireysel ve toplumsal sağlik üzerinde potansiyel bir etkileri bulunmaktadir. Ulaşım, iş, sosyal faaliyetler ve sağlık hizmetlerine erişim imkânı sağlayarak sağlığı teşvik edilebilir ya da kazalar, hava ve gürültü kirliliği, diğer sosyal ve çevresel etkiler yoluyla da sağlı̆̆ın zarar görmesine neden olabilir. Şehir sağlığını iyileştirmeye yönelik stratejileri tanımlamak için kentsel ulaşım politikaları ve projelerinin, izlenmesi ve değerlendirilmesi gerekmektedir. ${ }^{36}$ Ulaşımı içeren politikaları şu şekilde örneklendirmek mümkündür;

"Kentiçi ulaşım türlerinin tek elden planlanmasinı, koordinasyonunu ve denetimini sağlayacak katılımcı nitelikli yerel ulaşım örgütleri geliştirilecektir. Ulusal düzeyde de kentiçi ulaşımı yönlendirici fonksiyonu olan bir birim oluşturulacaktır."15

"Toplu taşıma hizmetlerinin erişilebilirliğ $i$ ve kalitesi yükseltilecektir. "16

"Belli büyüklügün üzerindeki kentlerde ulaşım ve trafik planları hazırlanacaktır."16

"Kentiçi ulaşımda trafik yönetimi ve toplu taşıma hizmetlerinde bilgi teknolojileri ve akıllı ulaşım sistemlerinden etkin bir şekilde faydalanılacaktır."18

"Özellikle büyükşehirlerde, kentiçi ulaşım ă̆ında dinamik yolcu, sürücü ve yaya bilgilendirme sistemleri kurulacaktır."19

\section{Çevre ve \\ Ekosistemlerin \\ Sürdürülebilirliği}

Tablo 2'de Çevre ve Ekosistemlerin Sürdürülebilirliği başlı̆̆ altında yer alan politikaların planlara göre dağılımları gösterilmiştir. Çevre ve Ekosistemlerin Sürdürülebilirliği konusunda Üçüncü BYKP'de en az politika (n:3) yer alırken en yer almaktadır. Planlarda, Çevre ve Ekosistemlerin Sürdürülebilirliği başlığı altında yer alan toplam politika sayısı 110'dur. Tablo 3'de planlarda, Çevre ve Ekosistemlerin Sürdürülebilirliği başlı̆̆ altında yer alan toplam kod sayıs1 159'dur.

Çevre ve Ekosistemlerin Sürdürülebilirliği başlığında yer alan politikalar incelendiğinde; içme suyu, kanalizasyon, atık, su ve hava kirliliği, çevre, enerji, kalite ve standart kavramları öne çıkmaktadır. Birinci BYKP'den itibaren tüm planlarda kalite ve standart kavramının yer alması şehir sağlığına katkı sağlaması açısından önem arz etmektedir. Küresel iklim değişikliği ve meydana gelen sonuçları hakkında politika oluşturulmasına yönelik Yedinci BYKP ve sonrasindaki planlarda buna yönelik kavramlara rastlanmaktadır. Kentsel yaşam tarzı, modern insan ekolojisinin temel taşıdır. Çevre ve insan sağlığı arasında yakın bir ilişkili bulunmaktadır. Sağlıklı bir çevre olmadan insan sağlığı iyileştirilemez veya garanti edilemez. Kentsel çevrenin insan sağlı̆̆ üzerindeki etkilerini; kentleşmenin getirdiği sosyal değişiklikler ve bu değişikliklerin davranışsal sağlık riskleri üzerindeki etkileri, kentsel fiziksel çevre ve çeşitli mikrobiyolojik riskler ve modern kentsel nüfusun büyük ölçekli çevresel etkileri olmak üzere üç başlıkta sınıflandırmak mümkündür. Çevre sağlığı sorunları bulaşıc1 ve bulaşıcı olmayan hastalıklardan, hava, su ve toprak kirliliği gibi nedenlerle kentsel ekosistemin bozulmasinda ve biyosfer sisteminin bozulmasına kadar karmaşık ve çok boyutludur. Sürdürülebilir bir kentsel ekosistem ve şehir sağlık tehlikelerinin azaltılması için çevre sorunlarına tüm tarafların stratejik yaklaşımı önemlidir. ${ }^{37}$ Çevre ve Ekosistemlerin Sürdürülebilirliği içeren politikaları şu şekilde örneklendirmek mümkündür;

"Çevre sorunlarının toplumsal değişim süreci ile birlikte çözüme kavuşturulması temel ilkedir."12

"Mahalli idareler tarafindan yürütülen kentsel ulaşım, katı atık değerlendirme ve 
arıtma, doğalgaz, jeotermal enerji tesisleri gibi önemli projelerin planlanmast, uygulanmast, standartlarin belirlenmesi ve finansmanı açısından merkezi ve mahalli idareler arasında işbirliği ve koordinasyon sağlanacaktır."

"Çevre ve kalkınma ile ilgili sağlıklı ve entegre bilgi sistemleri oluşturulacak, izleme, denetim ve raporlama altyapisı geliştirilecektir." 17

"Sürdürülebilir şehirler yaklaşımına uygun olarak şehirlerde atı ve emisyon azaltma, enerji, su ve kaynak verimliliği, geri kazanım, gürültü ve görüntü kirliliğinin önlenmesi, çevre dostu malzeme kullanımı gibi uygulamalarla çevre duyarlılığ yaşam kalitesi artırılacaktır."18

"Sıfır Atık Projesi uygulamaları
yaygınlaştırılacaktır."

"Ulusal Su $\quad$ Bilgi $\quad$ Sisteminin
yyggınlaştırılması
ağlanacaktır."19

\section{Doğal ve Yapay Afetlere Karşı Dayanım}

Tablo 2'de Doğal ve Yapay Afetlere Karş1 Dayanım başlığ́ altında yer alan politikaların planlara göre dağılımları gösterilmiştir. Doğal ve Yapay Afetlere Karşı Dayanım konusunda Birinci, İkinci, Dördüncü, Beşinci, Altıncı, Yedinci ve Dokuzuncu BYKP'lerde politika yer almazken (n:0) en fazla politika (n:9) On Birinci BYKP'de yer almaktadır. Planlarda, Doğal ve Yapay Afetlere Karşı Dayanım başlığı altında yer alan toplam politika sayısı 15'dir. Tablo 3'de planlarda, Doğal ve Yapay Afetlere Karşı Dayanım başlığ 1 altında yer alan toplam kod sayısı 26'dır.

Doğal ve yapay afetlere karşı dayanım başlığında yer alan politikalar incelendiğinde; imar planları, afet mevzuatı, risk belirleme, zarar azaltma ve kentsel dönüşüm projeleri kavramları öne çıkmaktadır. Bu başlıktaki politikaların çoğu Sekizinci ve On Birinci BYKP'lerde yer almaktadır. Tüm konu başlıkları içerisinde en az kavram bu başlıkta tespit edilmiştir. Afetler, tarih boyunca insan varlığını etkilemiş ve sağlık ile ilgili göstergelerde en üstlerde yer almıştır. Son yıllarda, artan şehirleşme, ormansızlaşma ve çevresel bozulma oranları ve yüksek sıcaklıklar, aşırı yağışlar ve daha şiddetli rüzgâr ve su firtınaları gibi yoğunlaşan iklim değişlikleri nedeniyle afetlerin ölçeği genişlemektedir. Afetlerin sağlık etkileri, ani ölüm ve sakatlık ile ekolojik değişimlerin neden olduğu bulaşıcı ve bulaşıcı olmayan hastalıkları içermektedir. ${ }^{38}$ Gelecek yıllarda afetlerin, özelliklede sel ve firtınaların, iklim değişikliği nedeniyle daha da sık ve şiddetli hale geleceği düşüldügünde, şehir sağlı̆̆ 1 için bu konudaki politikaları önemi ve değerli kılmaktadır. Doğal ve yapay afetlere karşı dayanım içeren politikaları şu şekilde örneklendirmek mümkündür;

"Kentsel dönüşüm uygulamaları ve imara yeni açlacak alanlar ile sanayi alanlarının dönüşümü kapsamında şehir planlaması yapilırken şehrin afet geçmişi, afet tehlikeleri ve riskleri göz önünde bulundurulacaktır."19

\section{Yönetişim ve Katılım}

Tablo 2'de Yönetişim ve Katılım başlığ1 altında yer alan politikaların planlara göre dağılımları gösterilmiştir. Yönetişim ve Katılım konusunda Birinci ve Dokuzuncu BYKP'lerde en az politika (n:2) yer alırken en fazla politika (n:43) On Birinci BYKP'de yer almaktadır. Planlarda, Yönetişim ve Katılım başlığı altında yer alan toplam politika sayıs1 190'dır. Tablo 3'de planlarda, Yönetişim ve Katılım başlığı altında yer alan toplam kod sayıs1 218'dir.

Yönetişim ve katılım başlı̆̆ında yer alan politikalar incelendiğinde; katılım, standardizasyon, yatırım, strateji, plan, işbirliği, koordinasyon, eşgüdüm ve denetim kavramları öne çıkmaktadır. Tüm konu başlıkları içerisinde en fazla kavram bu başlıkta tespit edilmiştir. On Birinci BYKP'de yer alan kavramlar yönetim anlayışının çağın gerekliliklerine uyum sağlanmasının bir yansıması olarak görülebilir. 21. yüzyıldaki gelişmeler 1şığında, yönetişimde devlet merkezli bir yapıdan, devlet temelinde yönetişimin ortaklaşa üretildiği çok paydaşlı ve işbirlikçi bir yapıya geçilmesi kaçınılmaz olmuştur. 
Yönetişimdeki bu değişim sağlıkla ilgili çeşitli yaklaşımlara da yanmıştır. Şehir sağlığı için yönetişim yaklaşımında, sağlık sistemi dışında bulunan ve iş birliğini kolaylaştıran yapılar ve mekanizmalar desteklenmelidir. $\mathrm{Bu}$ konuda insanların katılımı belirleyici bir faktördür. $\mathrm{Bu}$ yaklaşımla, sistemler arası iş birliği, halk sağlığı politikaları ve tüm politikalarda sağlık yaklaşımı entegre edilebilir. Şehir sağlı̆̆ için yönetişim yerel idare faaliyetlerinin koordinasyonunu ve entegrasyonunu geliştirmenin yanı sıra iş birliği içinde sağlık, eşitlik ve sürdürebilirlik gibi kapsayıcı toplumsal hedeflere katkıda bulunmakta ve çeşitli izleme mekanizmaları aracılığıyla şehir sağlığı için hesap verilebilirlik sağlanmaktadır. ${ }^{39}$ Yönetişim ve katılım içeren politikaları şu şekilde örneklendirmek mümkündür;

"Belediyelerin, genellikle, programl, uzun süreli işlere ve yatırımlara ayıracak ödenekleri yetersizdir. $\mathrm{Bu}$ sebeple bu hizmetlerin gerektirdiği tesislerin kurulması ve işletilmesi sırasında halkın gönüllü katılması teşvik edilecektir."9

\begin{tabular}{lll}
\multicolumn{2}{c}{ "Yönetimin Bütünlüğ̈̈ ilkesi içinde } \\
çalışmaları ve kendilerine & verilmiş \\
görevlerin yerine getirilmesi & amacına
\end{tabular}

\section{SONUÇ VE ÖNERİLER}

$\mathrm{Bu}$ araştırmanın sonucunda, Birinci BYKP'den On Birinci BYKP'ye kadar olan süre içerisinde planlarda yer alan şehir sağlığı politikalarının sayısında düzensiz olmakla birlikte ciddi bir artış olmuştur. Şehir sağlığı politikalarının sayısındaki artış sağlık değerinin iyileştirilmesi açısından önemli olmakla birlikte Sağlık Hizmetleri, Nüfus Yapısı ve Demografik Eğilimler, Doğal ve Yapay Afetlere Karşı Dayanım konularındaki politikaların az olması bu alanlarda daha fazla politika üretilmesine ihtiyaç olduğunu göstermektedir. Kalkınma yönelik olarak demokratik, halkçı, birlikçi, bütünlükçü bir yaklaşımla üretici ve kaynak yaratıcı bir niteliğe kavuşturulmaları sağlanacaktır."12

"Kentlerimizdeki sosyal ve teknik altyapı yatırımlarını gerçekleştiren kurum ve kuruluşlar arasında eşgüdüm sağlanacaktır."16

"Akıllı uygulamaların sağhlk, ulaştırma, bina, enerji ile afet ve su yönetimi gibi alanlar başta olmak üzere kullanımı yaygınlaştırllacaktır. Şehirlerin bilgi ve iletişim teknolojileri alanındaki altyapı, kapasite ve beceri düzeyleri artırılarak akıllı kentlere dönüşmesi desteklenecektir."18

"Ülke genelinde coğrafi nitelikli mekânsal bilgi üreten ve kullanan kuruluşlar arasında birlikte çalışabilirlik esasları hayata geçirilecek; mekânsal planlara ve uygulamalara elektronik altlık oluşturacak bilgilerin öngörülen standartlarda üretilmesi ve paylaşılması sağlanacaktır."18

"Akullı şehir ekosistemi analiz edilerek girişimciler, sistem geliştiriciler, teknoloji sağlayıcılar gibi sektörün tüm paydaşları oluşturulacak dijital platformda buluşturulacaktır." 19 planlarında yer alan şehir sağlı̆̆ politikalarının sayısının artırılması, kamu politikalarının oluşturulmasında şehir sağlığ etkilerinin dikkate alınması ve politika yapicilarının konu hakkındaki farkındalıklarının artırılması önerilmektedir. $\mathrm{Bu}$ araştırma ile "şehir sağlı̆̆ ifadesi literatüre kazandırılmış ve konuyla ilgili eksikliklerin bir kısmı giderilmiş olsa da araştırmanın sınırlılıkları gereği şehir sağlığı politikaları konusunda yeni araştırmaların yapılması önerilmektedir.
1. Carrillo, F.J., Yigitcanlar, T, García, B. and Lönnqvist, A. (2014). Knowledge and The City: Concepts, Applications and Trends of Knowledge-Based Urban Development. New York: Routledge.
2. Wernham, A. and Teutsch, S.M. (2015). "Health in All Policies for Big Cities". Journal of Public Health Management and Practice, 21 (1), 56. 
3. World Health Organization. (1986). "Ottawa Charter for Health Promotion”. Health Promotion, 1 (4), 3-5.

4. World Health Organisation. (1988). "The Adelaide Recommendations: Healthy Public Policy". WHO and The Commonwealth of Australia.

5. World Health Organization. (2014). "Health in All Policies: Helsinki Statement”. Framework for Country Action.

6. Rudolph, L, Caplan, J, Mitchell, C, Ben-Moshe, K. and Dillon, L. (2013). "Health in All Policies: İmproving Health Through İntersectoral Collaboration”. NAM Perspectives.

7. World Health Organization. (1998). "City Health Profiles: A Review of Progress".

8. Keskin, H. ve Sungur, O. (2010). "Bölgesel Politika Ekseninde Yaşanan Dönüşüm: Türkiye'de Kalkınma Planlarında Bölgesel Politikaların Değișimi”. Süleyman Demirel Üniversitesi Fen-Edebiyat Fakültesi Sosyal Bilimler Dergisi, 2010 (21), 271-293.

9. T.C. Başbakanlık Devlet Planlama Teşkilatı Müsteşarlığı. (1963). "Birinci Beş Yıllık Kalkınma Planı (1963-1967)". Erișim adresi: https://www.sbb.gov.tr/wpontent/uploads/2018/11/Birinci-Be\%C5\%9F-

Y\%C4\%B111\%C4\%B1k-Kalk\%C4\%B1nma-Plan\%C4\%B11963-1967\%E2\%80\%8B.pdf (Erişim tarihi: 14.02.2021).

10. T.C. Başbakanlık Devlet Planlama Teşkilatı Müsteşarlığı. (1968). "İkinci Beş Yıllık Kalkınma Planı (1968-1972)". Erişim adresi: https://www.sbb.gov.tr/wpcontent/uploads/2018/11/\%C4\%B0kinci-Be\%C5\%9FY\%C4\%B111\%C4\%B1k-Kalk\%C4\%B1nma-Plan\%C4\%B11968-1972\%E2\%80\%8B.pdf (Erişim tarihi: 14.02.2021).

11. T.C. Başbakanlık Devlet Planlama Teşkilatı Müsteşarlığı. (1972). "Üçüncü Beş Yıllık Kalkınma Planı (1973-1977)". Erişim adresi: https://www.sbb.gov.tr/wpcontent/uploads/2018/11/\%C3\%9C\%C3\%A7\%C3\%BCnc\% $\mathrm{C} 3 \% \mathrm{BC}-\mathrm{Be} \% \mathrm{C} 5 \% 9 \mathrm{~F}-\mathrm{Y} \% \mathrm{C} 4 \% \mathrm{~B} 111 \% \mathrm{C} 4 \% \mathrm{~B} 1 \mathrm{k}-$

Kalk\%C4\%B1nma-Plan\%C4\%B1-1973-

1977\%E2\%80\%8B.pdf (Erişim tarihi: 14.02.2021).

12. T.C. Başbakanlık Devlet Planlama Teşkilatı. (1978). "Dördüncü Beș Yıllık Kalkınma Planı (1979-1983)". Erișim adresi: https://www.sbb.gov.tr/wpcontent/uploads/2018/11/D\%C3\%B6rd\%C3\%BCnc\%C3\%B $\mathrm{C}-\mathrm{Be} \% \mathrm{C} 5 \% 9 \mathrm{~F}-\mathrm{Y} \% \mathrm{C} 4 \% \mathrm{~B} 111 \% \mathrm{C} 4 \% \mathrm{~B} 1 \mathrm{k}$

Kalk\%C4\%B1nma-Plan\%C4\%B1-1979-

1983\%E2\%80\%8B.pdf (Erișim tarihi: 14.02.2021).

13. T.C. Başbakanlık Devlet Planlama Teşkilatı. (1984). "Beşinci Beş Yıllık Kalkınma Planı (1985-1989)". Erişim adresi: https://www.sbb.gov.tr/wpcontent/uploads/2018/11/Be\%C5\%9Finci-Be\%C5\%9FY\%C4\%B111\%C4\%B1k-Kalk\%C4\%B1nma-Plan\%C4\%B11985-1989.pdf (Erişim tarihi: 14.02.2021).

14. T.C. Başbakanlık Devlet Planlama Teşkilatı. (1989). "Altıncı Beş Yıllık Kalkınma Planı (1990-1994)". Erișim adresi: https://www.sbb.gov.tr/wpcontent/uploads/2018/11/Alt\%C4\%B1nc\%C4\%B1Be\%C5\%9F-Y\%C4\%B1111\%C4\%B1k-Kalk\%C4\%B1nmaPlan\%C4\%B1-1990-1994\%E2\%80\%8B.pdf (Erişim tarihi: 14.02.2021).

15. T.C. Başbakanlık Devlet Planlama Teşkilatı. (1995). "Yedinci Beş Yıllık Kalkınma Planı (1996-2000)". Erişism adresi: https://www.sbb.gov.tr/wpcontent/uploads/2018/11/Yedinci-Be\%C5\%9FY\%C4\%B111\%C4\%B1k-Kalk\%C4\%B1nma-Plan\%C4\%B11996-2000\%E2\%80\%8B.pdf (Erişim tarihi: 14.02.2021).

16. T.C. Başbakanlık Devlet Planlama Teşkilatı. (2000). "Sekizinci Beș Yı1lık Kalkınma Planı (2001-2005)". Erișim adresi: https://www.sbb.gov.tr/wpcontent/uploads/2018/11/Sekizinci-Be\%C5\%9F-

Y\%C4\%B111\%C4\%B1k-Kalk\%C4\%B1nma-Plan\%C4\%B12001-2005.pdf (Erişim tarihi: 14.02.2021).
17. T.C. Başbakanlık Devlet Planlama Teskilatı. (2006). "Dokuzuncu Kalkınma Planı (2007-2013)". Erişim adresi: https://www.sbb.gov.tr/wp-

content/uploads/2018/11/Dokuzuncu-Kalk\%C4\%B1nmaPlan\%C4\%B1-2007-2013\%E2\%80\%8B.pdf (Erişim tarihi: 14.02.2021)

18. T.C. Kalkınma Bakanlığı. (2013). "Onuncu Kalkınma Planı (2014-2018)". Erișim adresi: https://www.sbb.gov.tr/wpcontent/uploads/2018/11/Onuncu-Kalk\%C4\%B1nmaPlan\%C4\%B1-2014-2018.pdf (Erişim tarihi: 14.02.2021).

19. T.C. Cumhurbaşkanlığı Strateji ve Bütçe Başkanlığı. (2019) “On Birinci Kalkınma Planı (2019-2023)". Erișim adresi: https://www.sbb.gov.tr/wpcontent/uploads/2019/11/ON_BIRINCI_KALKINMAPLANI_2019-2023.pdf (Erişim tarihi: 14.02.2021).

20. Bowen, G.A. (2009). "Document Analysis as a Qualitative Research Method". Qualitative Research Journal, 9 (2), 27 40

21. Dalglish, S.L, Khalid, H. and McMahon, S.A. (2020) "Document Analysis in Health Policy Research: The READ Approach". Health Policy and Planning, 2020, 1-8.

22. Yıldırım, A. ve Simsek, H. (2018). Sosyal Bilimlerde Nite Araştırma Yöntemleri (11. Baskı). Ankara: Seçkin Yayınc1lik.

23. Sağlık Hizmetlerinin Sosyalleștirilmesi Hakkında Kanun (1961). Resmi Gazete. 10705, 12/1/1961

24. Çavmak, Ş. ve Çavmak, D. (2017). "Türkiye'de Sağlık Hizmetlerinin Tarihsel Gelișimi ve Sağllkta Dönüşüm Programı”. Sağlık Yönetimi Dergisi, 1 (1), 48-57.

25. Sağlık Bakanlığı. (2008). Türkiye Sağlıkta Dönüşüm Programı İlerleme Raporu. Ankara: Sağlık Bakanlığı Yayın No: 749.

26. Keskin, H. ve Sungur, O. (2010). "Bölgesel Politika Ekseninde Yaşanan Dönüşüm: Türkiye'de Kalkınma Planlarında Bölgesel Politikaların Değissimi”. Süleyman Demirel Üniversitesi Fen-Edebiyat Fakültesi Sosyal Bilimler Dergisi, 2010 (21), 271-293.

27. McKeehan, I.V. (2000). "A Multilevel City Health Profile of Moscow”. Social Science \& Medicine, 51 (9), 12951312 .

28. Darıc1, B. (2018). "Para Politikası ve Konut Fiyatlar İlişkisi: Türkiye Ekonomisi İçin Ampirik Bir Analiz". Anemon Muş Alparslan Üniversitesi Sosyal Bilimler Dergisi, 6 (18), 221-228.

29. Çelikkaya, S, Dağl1, İ. ve Yaman, H. (2019). "Planlı Dönem Sonrası Türkiye'de Bilim Ve Teknoloji Politikaları: Kalkınma Planları Özelinde Kavramsal Bir Bakış". Paradoks Ekonomi Sosyoloji ve Politika Dergisi, 15 (2), 245-260.

30. Suglia, S.F, Duarte, C.S. and Sandel, M.T. (2011). "Housing Quality, Housing Instability and Materna Mental Health". Journal of Urban Health, 88 (6), 1105 1116

31. Tiryakioğlu, M. (2016). "Türkiye Ekonomisinde Geç Kalkınmanın ve Yerli Üretimin Ekonomi Politiği’. Ege Academic Review, 16 (2).

32. Solak, M. (2018). Sağlık Ekonomisi. Eskișehir: T.C. Anadolu Üniversitesi Yayını No: 3218.

33. Akça, Y, Şahan, G. ve Tural, A. (2017). “Türkiye'nin Kalkınma Planlarında Eğitim Politikalarının Değerlendirilmesi”. Uluslararası Kültürel ve Sosyal Araştırmalar Dergisi (UKSAD), 3 (Özel Sayı 2), 394-403.

34. Aytaç, Ö. ve Kurtdaş M.Ç. (2015). "Sağlık-Hastalığın Toplumsal Kökenleri ve Sağlı Sosyolojisi”. Firat Üniversitesi Sosyal Bilimler Dergisi, 25 (1), 231-250. 
35. George, L.M. (2021). "Neighborhood Deprivation as a Measure of Social Need and Healthcare Utilization: A Review of the Literature". Doctoral Thesis, University of Pittsburgh, Pittsburgh.

36. Becerra, J.M, Reis, R.S, Frank, L.D, Ramirez-Marrero, F.A, Welle, B, Arriaga Cordero, E, Mendez Paz, F, Crespo, C, Dujon, V, Jacoby, E, Dill, J, Weigand, L. and Padin, C.M. (2013). "Transport and Health: a Look at Three Latin American Cities". Cadernos De Saude Publica, 29 (4), 654 666.

37. McMichael, A.J. (2000). "The Urban Environment and Health in A World Of İncreasing Globalization: İssues for Developing Countries". Bulletin of the World Health Organization, 78, 1117-1126.

38. Leaning, J. and Guha-Sapir, D. (2013). "Natural Disasters, Armed Conflict and Public Health". New England Journal of Medicine, 369 (19), 1836-1842.

39. Kickbusch, I. and Gleicher, D. (2012). "Governance for Health in: the 21st Century". World Health Organization Regional Office for Europe. 